\title{
The Curious Case of the Grumpy Union Member
}

\author{
Sinisa Hadziabdic*
}

Abstract: Relying on the data of the Swiss Household Panel, the paper aims to make sense of the puzzling dissatisfaction union members exhibit in most dimensions of their job. A longitudinal approach reveals that the dissatisfaction is to a large extent explained by contextual and individual time-invariant unobserved heterogeneity. A decline in job satisfaction is for many workers the main reason to join a union. Job satisfaction climbs back as the years of membership increase, which confirms that unions do indeed have positive effects on the professional well-being of their members.

Keywords: Labor unions, job satisfaction, panel data, dynamic effects.

\section{Le curieux cas du membre syndical grincheux}

Résumé: En utilisant les données du Panel suisse de ménages, le papier vise à rendre compte de l'étonnante insatisfaction des membres syndicaux dans la plupart des aspects de leur travail. Une approche longitudinale révèle que l'insatisfaction s'explique dans une large mesure par l'hétérogénéité non-observée entre membres et non-membres au niveau contextuel et individuel. Une baisse de la satisfaction au travail est pour de nombreux travailleurs la principale raison d'adhérer à un syndicat. La satisfaction au travail remonte à mesure que le nombre d'années d'adhésion augmente, ce qui confirme que les syndicats ont effectivement des effets positifs sur le bien-être professionnel de leurs membres.

Mots-clés: Syndicats, satisfaction au travail, données de panel, effets dynamiques.

\section{Der kuriose Fall des mürrischen Gewerkschaftsmitglieds}

Zusammenfassung: Anhand der Daten des Schweizer Haushalt-Panels beabsichtigt das Paper die rätselhafte Unzufriedenheit von Gewerkschaftsmitglieder in den meisten Dimensionen ihrer Arbeit zu erklären. Ein longitudinaler Ansatz zeigt, dass die Unzufriedenheit weitgehend durch kontextuelle und individuelle zeitinvariante, unbeobachtete Heterogenität erklärt wird. Ein Rückgang der Arbeitszufriedenheit ist für viele Arbeiter der Hauptgrund für den Beitritt zu einer Gewerkschaft. Die Arbeitszufriedenheit steigt während der Mitgliedschaftserfahrung zurück, was bestätigt, dass Gewerkschaften tatsächlich positive Wirkungen auf das berufliche Wohlergehen ihrer Mitglieder haben.

Schlüsselwörter: Gewerkschaften, Arbeitszufriedenheit, Paneldaten, Dynamische Effekte.

* Max Planck Institute for the Study of Societies (MPIfG), Cologne, Germany, hs@mpifg.de. 
Explaining individual thinking and behavioral patterns is a challenging task. Every individual is subject to different sets of forces that influence the way she interacts with and interprets the surrounding world. While personal attitudes and beliefs are important elements to take into account, structural constraints and contextual conditions are often relevant determinants in explaining the variability between individuals. Apparently paradoxical situations in which there is a mismatch between the attitudes of an individual and her behavior offer the opportunity to examine the potential contradictory influences of individual penchants and external constraints.

This type of paradox is provided by the link between union membership and job satisfaction. Despite their increased involvement in the public and political sphere (e. g. Baccaro et al. 2003; Streeck and Hassel 2003) unions' main scope of activity is and remains the protection and the improvement of their members' professional well-being. Therefore, it is puzzling to discover that union members are less satisfied than non-members with most dimensions of their job. The paper aims to make sense of this apparent puzzle for the Swiss case. The focus on Switzerland is motivated by: 1) the availability of rare high-quality longitudinal data to explore the issue in a new light; 2) the opportunity to examine in a coordinated market economy a question examined so far only in liberal market economies. While solving the paradox, we indirectly evaluate whether members still see unions as a relevant actor to refer to when experiencing professional issues. In addition, job satisfaction is a dimension at the core of the functioning of the labor market, linked to labor productivity and turnover (Mangione and Quinn 1975; Akerlof et al. 1988; McEvoy and Cascio 1985).

Since the act of joining a union is in general the result of a voluntary choice, one of the main theories that tries to make sense of the link between union membership and job satisfaction is based on a process of self-selection. Union members may be more dissatisfied with their job even before becoming affiliated and the experience of union membership may not have a negative effect in itself. Job satisfaction, like every attitude, is influenced by a large number of factors, many of which may be unobservable. Existing cross-sectional approaches may be hence inadequate to estimate the causal link between union membership and job satisfaction. Working with panel data and modeling changes in the dependent variable through changes in the independent one(s), it is possible to control for all time-invariant potentially omitted factors and to show that the differentials between members and non-members in terms of job satisfaction are to a large extent the consequence of unobserved, rather than observed, heterogeneity between members and non-members.

Since job satisfaction is an attitudinal outcome variable, it can be influenced by both objective changes in an individual's work situation (exerting in most cases an immediate effect) and changes in the way the same work context is subjectively interpreted (based in most cases on gradual attitudinal variations). The second type 
of mechanism justifies the exploration of a dynamic dimension that illustrates how job satisfaction may vary throughout the membership trajectory. In particular, prospective members may undergo a gradual learning process before being able to see unions as an actor that can have an impact on their job satisfaction. After joining, unions may also require substantial time to influence the job satisfaction level of their members by acting on objective working conditions but also by changing the way members perceive them. The results are used to reinterpret the literature on the link between union membership and job satisfaction. Unions in Switzerland appear to be doing what they are supposed to by increasing the job satisfaction level of their members. However, the process through which that happens is less straightforward than previously thought and operates through multiple channels. More generally, any time attitudinal variables are used as outcomes, the issues described above are likely to arise. Unobserved heterogeneity and the presence of a dynamic dimension are aspects always relevant to consider. A longitudinal approach that requires the availability of individual-level panel data turns out to be indispensable to uncover such effects.

The remainder of the paper is structured as follows. In the second section, we summarize the main approaches developed in the existing literature to make sense of the link between union membership and job satisfaction. We then describe the data we employ to examine this relationship in Switzerland and the empirical strategies we adopt. In the fourth section, we illustrate the empirical findings before discussing them and drawing some general conclusions.

\section{Self-selection and/or a process of internal politicization: Theoretical framework}

The link between job satisfaction and union membership has received lots of attention in the existing literature. Job satisfaction is a concept that operationalizes the perception an individual has of her job in general or of specific dimensions of it ( $\mathrm{Lu}$ et al. 2005). As such, it can be considered a unitary concept that measures the overall appreciation of one's job or a multidimensional construct that implies separate facets. Below we consider both a measure of the overall level of job satisfaction and three specific dimensions (income, work atmosphere, and risk of unemployment). Income is one of the key factors determining the overall level of job satisfaction (Herzberg 1966), the appreciation of the work atmosphere is linked to the relational needs of every individual (Maslow 1970), while the self-evaluated risk of unemployment refers to the security needs of every worker that are a prerequisite to be able to enjoy what happens at the workplace on a daily basis (Maslow 1970).

At a descriptive level, union members are found to be less satisfied than non-members with most dimensions of their job. The disadvantage is particularly 
pronounced in all aspects related to internal professional dynamics (tasks and relationships with colleagues and supervisors) and has been confirmed in Europe for the UK (Bender and Sloane 1998; Bryson et al. 2004; Heywood et al. 2002; Powdthavee 2011), in North America for Canada (Renaud 2002) and the United States (Artz 2010; Berger et al. 1983; Borjas 1979; Freeman 1978; Freeman 1980; Freeman and Medoff 1984; Hersch and Stone 1990; Pfeffer and Davis-Blake 1990; Gordon and Denisi 1995; Rees 1991), and in Australia (Miller 1990). More varied empirical findings are found when looking at external outcomes (income and job security), union members showing an advantage in these dimensions in the UK and in Canada (Meng 1990; Powdthavee 2011), are similar to non-members in Australia (Miller 1990), while they are disadvantaged in both dimensions in the US (Freeman and Medoff 1984; Brochu and Morin 2012). Therefore, the general picture that emerges is a lower satisfaction of union members especially when looking at the internal logics of their jobs. All these studies are based on countries that can be grouped into liberal market economies (Hall and Soskice 2001). With a centralized industrial relations regime at the industry-level and a consensual political system (Lehmbruch 1993; Lijphart 1998), Switzerland is usually considered a coordinated market economy (Hall and Soskice 2001). It is hence interesting to see whether the pattern of union member dissatisfaction holds also in a different institutional context.

In the following paragraphs, we review three main groups of approaches that make sense of the puzzling job dissatisfaction of union members when compared to non-members.

Since unions are meant to positively affect the working conditions of their members, the first explanation of their lower job satisfaction when compared to non-members supposes that this dissatisfaction is to be traced back to differences pre-existing the joining act. Both structural and individual factors may lead wageearners that join unions to be less satisfied with their job situation even before becoming affiliated when compared to workers not joining a union. In fact, typical blue-collar union jobs are objectively characterized by worse working conditions, a tighter self-realization leeway, stricter hierarchical relationships, and rarer promotion opportunities than the average job (Borjas 1979; Worrall and Butler 1983). At the individual level, some wage-earners may be more likely to join unions than other ones that share the same working conditions because they are more sensitive to certain issues at the workplace and are more dissatisfied with them to begin with. In other words, both structural and individual factors may be responsible for a lower level of job satisfaction to begin with that, in turn, represents the main reason for certain categories of wage-earners to self-select themselves into unions. This scenario can also be seen as a case of reversed causality, the outcome variable we consider (job satisfaction) affecting the main independent variable (the union membership status). Recent evolutions in the labor market imply a growing liberalization of industrial relations (Baccaro and Howell 2017) and an increase of the share of jobs in 
the service sector to the detriment of the strongly unionized manufacturing sector (Avdagic and Baccaro 2016). These trends suggest that punctual membership events related to a sudden decrease in job satisfaction may have become more frequent than in the past. Union membership is no longer a customary practice for most workers and it tends to reflect an individual choice, a decrease in job satisfaction being the potential key driver.

Empirically, selection effects explaining the link between job satisfaction and union membership have been confirmed by including a large enough number of control variables that make the coefficient of union membership insignificant (Bender and Sloane 1998; Renaud 2002). Since some of the control variables used by cross-sectional literature are endogenous, a more convincing strategy is provided by the use of instrumental variables. Working with a very rich dataset on UK unions, Bryson et al. (2004) show that union membership has a negative relationship with job satisfaction even after including a rich set of observed controls. The relationship becomes insignificant only when instrumenting the union membership status. They conclude that the residual job dissatisfaction between members and non-members is related to unobservable personality traits. Adopting a different empirical strategy, Gordon and Denisi (1995) reach the same conclusion when comparing workers members and non-members exposed to the same working conditions. However, their results suffer from an issue of external validity since they cannot be generalized to contexts other than those they considered.

Aside from the studies cited in the previous paragraph, the bulk of the existing literature interprets the negative association between job satisfaction and union membership as a proper causal effect of involvement in union dynamics. In fact, in most articles, the negative effect of union membership remains significant even after including a large number of observed control variables. Hirschman's exit-voice theory is the main approach that allows linking these differences to union membership (Hirschman 1970; Freeman and Medoff 1984). The theory states that, when facing issues in an organization, individuals can either try to redress the situation by voicing their concerns or exit it. The voice option is more often used by union members, being more likely to detect work-related issues and to communicate them to unions. In the long run, besides becoming sensitive to objective professional problems, members may undergo a process of politicization (Borjas 1979). Members may become so attached to unions' priorities, socialized into a union culture that leads them to voice concerns to support the unions' cause even independently of objective work issues.

If a socialization/politicization process takes indeed place, this implies that job satisfaction is not only the reflection of objective working conditions but also embodies subjective considerations (Pencavel 2009). Working conditions are not only objectively evaluated by individuals but are also subjectively perceived depending on their own experiences and interpretations. Union members may express 
satisfaction levels lower than their actual satisfaction in order to strategically support unions' goals. Union membership can influence job satisfaction by acting on objective working conditions and by affecting how objective elements are perceived and expressed in survey questions. This is empirically supported by the fact that, among union members, a lower job satisfaction does not lead to a higher propensity to leave one's job (Borjas 1979; Freeman 1978; Kochan and Helfman 1981; Leigh 1986; Lincoln and Boothe 1993) and is unrelated to the desire to have a union at the workplace (Leigh 1986). A lower job satisfaction does not lead to negative behavioral and attitudinal outcomes one would expect if it represented only genuine negative evaluations of union members' work situation.

Other strands of literature provide alternative interpretations of the ambiguous link between job satisfaction and job turnover. Kochan and Helfman (1981) highlight that the costs of leaving union jobs are higher than for non-union jobs. The former are associated with a number of benefits (job security, wage premiums, social packages) not easy to find in non-union jobs. These "bread and butter" issues are more important than having a pleasant job content. The exit option is in most cases not even considered since work disengagement, low productivity, or absenteeism are much more affordable reactions to job dissatisfaction (Hammer and Avgar 2005). Allen (1984) confirms that union members exhibit a higher tendency to be absent from their job, which suggests that their lower job satisfaction may be genuine.

It is hence possible to link low job satisfaction and low job turnover without having to suppose that the former is the result of distorted declarations. However, we still have to explain how a low job satisfaction does not negatively influence the desire for the presence of a union at the workplace (Leigh 1986). In fact, dishonest declarations may appear in real life but should be much less prevalent in anonymous survey questionnaires (Bender and Sloane 1998). The solution to this apparent contradiction can be found by pushing further the mechanism through which unions can affect the subjective aspects of job satisfaction. If we conceptualize job satisfaction as an encounter between objective working conditions and the expectations an individual has about them (Hulin et al. 1985), we can suppose that unions can influence the subjective side of job satisfaction not only through an impact on false declarations but also by affecting the frame of reference through which objective working conditions are interpreted. The same objective working conditions may be interpreted differently by different individuals. Personality traits, past experiences, and current involvement in union dynamics may affect such interpretative frames. Even if they provide improvements in objective working conditions, unions may lead to a general decrease of job satisfaction if, at the same time, they increase the satisfaction standards of their members. By interacting with union leaders and other members, an individual may realize that what was good enough in certain job dimensions before joining unions is no longer good enough after having become affiliated. This hypothesis is compatible with a pattern that simultaneously implies a 
lower job satisfaction among union members and their positive opinion on unions. Empirically, two studies attempted to confirm the effect of unions on the interpretative frames of their members. Berger et al. (1983) and Schwochau (1987) show that the importance given to different dimensions of job satisfaction mediates the link between union membership and the satisfaction in such dimensions. Even though useful to highlight how unions may affect the importance given to different job dimensions by their members, the operationalizations used in the two articles are obviously endogenous since it is impossible to measure separately the satisfaction in a given dimension and the importance given to it. Alternatively, it is also possible to become less satisfied if unions' actions do not meet the expectations of a wage-earner who joined hoping in an improvement of her job situation.

Finally, we highlight that, while a selection effect perspective does not allow explaining any dynamic effects of union membership on job satisfaction, the exitvoice perspective, the presence of a socialization/politicization process, and/or the change of the interpretative frame of reference are compatible with the presence of dynamic changes of union membership related to the duration of membership and to past union membership experiences. If we conceptualize union membership (Gomez and Gunderson 2004) or associational involvement in general (Hooghe 2003) as an experience good whose benefits are gradually acquired and that may not dissipate after leaving the membership status, it is possible to show that union membership can have positive job satisfaction effects especially on first-time members at the beginning of their membership experience (Artz 2010), probably through an impact on objective working conditions. However, the self-declared satisfaction with union achievements tends to decrease with the duration of membership (Artz 2010) since the benefits provided by unions become taken for granted or the satisfaction standards become gradually higher. After leaving, job satisfaction may recover only gradually. Powdthavee (2011) provides additional dynamic analyses showing that job satisfaction tends to drop right before joining a union, probably causing the decision to become affiliated. Satisfaction partially recovers during the membership phase despite never reaching pre-membership levels, which is consistent with the presence of an interplay between objective and subjective considerations that determine job satisfaction.

Summing up, disentangling the link between union membership and job satisfaction requires to consider selection and causal effects, objective and subjective determinants of the level of satisfaction, and potential longitudinal effects related to what happens during the overall membership trajectory (before, during, and after having left a union) and the residual signs of past membership experiences. 


\section{Empirical ingredients and strategies: Data and methods}

In this section, we start by describing the data we employ to examine the link between union membership and four dimensions of job satisfaction in Switzerland. We then illustrate the empirical strategies we adopt to understand to what extent, on average, unions influence their members' job satisfaction and how the effect(s) may vary dynamically throughout the membership trajectory.

\subsection{Data: The Swiss Household Panel}

The link between union membership and job satisfaction is examined in Switzerland using the data of the Swiss Household Panel (SHP). In Table 1, we describe the questions used to operationalize the union membership status and the four dimensions of job satisfaction (working conditions, income, work atmosphere, risk of unemployment) we take into account.

\begin{tabular}{|c|c|c|c|}
\hline Variable & Question(s) & Answer options & Waves \\
\hline Union membership & $\begin{array}{l}\text { I will now read out a list of associa- } \\
\text { tions and organisations. Could you tell } \\
\text { me for each of them whether you are } \\
\text { an active member, a passive member } \\
\text { or not a member? Trade union, em- } \\
\text { ployees association }\end{array}$ & $\begin{array}{l}\text { - Non-member (0) } \\
\text { - Member (1) } \\
\text { (either passive or } \\
\text { active member) }\end{array}$ & $\begin{array}{l}\text { 1999-2009, 2011, } \\
2014,2017\end{array}$ \\
\hline $\begin{array}{l}\text { Satisfaction with } \\
\text { working conditions }\end{array}$ & $\begin{array}{l}\text { On a scale from } 0 \text { "not at all satisfied" } \\
\text { to } 10 \text { "completely satisfied" can you } \\
\text { indicate your degree of satisfaction } \\
\text { for each of the following points? Your } \\
\text { working conditions }\end{array}$ & $0-10$ & 1999-2017 \\
\hline $\begin{array}{l}\text { Satisfaction with } \\
\text { income }\end{array}$ & The income you get from your job & $0-10$ & 1999-2017 \\
\hline $\begin{array}{l}\text { Satisfaction with } \\
\text { work atmosphere }\end{array}$ & $\begin{array}{l}\text { The atmosphere between you and your } \\
\text { work colleagues }\end{array}$ & $0-10$ & 1999-2017 \\
\hline $\begin{array}{l}\text { Risk of unem- } \\
\text { ployment: Next } \\
12 \text { months }\end{array}$ & $\begin{array}{l}\text { How do you evaluate the risk of be- } \\
\text { coming personally unemployed in the } \\
\text { next } 12 \text { months, if } 0 \text { means "no risk at } \\
\text { all" and } 10 \text { "a real risk"? }\end{array}$ & $0-10$ & 1999-2017 \\
\hline
\end{tabular}

We consider a dichotomous union membership status (non-member or member) by merging passive and active members. ${ }^{1}$ Regarding the four dimensions of job satisfaction, they were chosen both because of pragmatic reasons (they are available in all

1 This choice is warranted since we do not have enough statistical power to obtain reliable results on continuous passive or active members for the dynamic analyses presented below. 
survey waves) and because they provide a varied set of job satisfaction dimensions. The satisfaction with working conditions can be seen as a variable operationalizing the satisfaction with one's job in general. Income satisfaction considers one of the key dimensions influencing the overall level of job satisfaction, explaining professional motivation, and potentially linked to wage premiums unions may be able to guarantee to their members. The perception of the work atmosphere focuses more precisely on the relational aspects of the work environment. The self-evaluated risk of unemployment is a key measure of job security on which unions should have an impact and that is particularly relevant when taking into account today's liberalization and flexibilization trends.

In addition to these key variables, we consider a series of standard control variables: sex, age class, education level, citizenship, region of residence, marital status, and time dummies. Differently from certain articles in the existing literature (e.g. Bender and Sloane 1998; Renaud 2002), these controls are clearly exogenous and do not intervene as mediators of the relationship of interest, two very important characteristics since we aim to tease out causal effects (Wooldridge 2010, 53-57). All analyses are based on the subset of wage-earners, ${ }^{2}$ i. e. the category of individuals most likely to join a union. Considering the years in which the union membership variable is available, our analyses are representative of the Swiss population between 1999 and 2009, 2011, 2014, and 2017 and are based on 17636 distinct individuals and 56325 observations. Descriptive statistics on independent, dependent, and control variables are available in Table A1 of the Appendix.

\subsection{Average and dynamic effects: Empirical strategies}

We start by examining the link between union membership and the four outcome variables by estimating average treatment effects, i. e. by looking at the extent to which joining a union is capable of modifying, on average, the level of job satisfaction. In order to do that, we consider the following functional form:

$$
Y_{i t}=\alpha+\beta M_{i t}+C_{i t}^{\prime} \delta+v_{i}+\mu_{i t}, \quad \text { for } i=1,2, \ldots, N \text { and } t=1,2, \ldots, T
$$

where the sub-scripts $\mathrm{i}$ and t represent individuals and time points, respectively; $\mathrm{Y}_{\text {it }}$ is a job satisfaction dimension; $\alpha$ an intercept term constant across individuals and time periods; $\beta$ is the coefficient of the union membership status; $M_{i t}$ a dummy variable coded as 0 if the individual is not a member in a given year and 1 if she is a member; $\mathrm{C}_{\mathrm{it}}$ is the vector of the observed control variables described above; $\delta$ the coefficients of the control variables; $v_{\mathrm{i}}$ corresponds to all variables that affect the dependent variable and vary across individuals but not over time; $\mu_{\mathrm{it}}$ represents

2 The definition of wage-earner is the one of the International Labour Organization. 
all variables not included in the model that affect the dependent variable and vary across individuals and over time.

We estimate three types of models. In the first one, we do not include any control variable (setting $C$ as the null vector), and estimate the $\beta$ coefficient of interest through ordinary least squares (OLS). This gives the observed differential in job satisfaction between non-members and members. If the decision to join a union was unrelated to a wage-earner's job satisfaction, this observed difference would already represent the desired causal effect of union membership. Since this assumption is unlikely to hold, the bulk of the existing cross-sectional literature tries to tackle the likely correlation between union membership and the error term(s) by including a set of observed controls supposed to capture omitted variables that influence both the act of joining and job satisfaction. This is what we do in a second pooled OLS model where we include the control variables described in the previous section. Finally, we exploit the longitudinal structure of the data in order to also partial out the endogeneity coming from time-invariant omitted variables included in the idiosyncratic error term $v_{\mathrm{i}}$. We do that by estimating the specification in equation (1) through a fixed effects model.

Since most aspects of an individual's life do not change at all or do not change very often over time, a fixed effects model controls for a huge set of potential omitted variables. Nevertheless, the model is still exposed to issues of time-varying endogeneity: time-varying omitted variables and time-varying reversed causality. Time-varying reversed causality is particularly relevant with the research question at hand since a change (in particular a decrease) in job satisfaction may be one of the primary reasons that motivate a wage-earner to join a union. Instead of dealing with strategies based on untestable assumptions such as instrumental variable estimators, we draw inspiration from Powdthavee's (2011) article and examine the issue by generalizing our specification on the previous page. We consider the link between union membership and job satisfaction in a dynamic fashion by taking into account attitudinal changes throughout the membership trajectory. In order to do that, we partition the membership status in a series of dummies, each one representing a specific moment in the membership trajectory. We consider ten dummies that identify yearly membership durations: a dummy coded 1 if the individual will become a member in the following 5 years or more and 0 otherwise (we do not go beyond 5 years because few individuals have long enough spells), a dummy coded 1 if the individual will become a member in the following 4 years and 0 otherwise, ..., a dummy coded 1 if the individual will become a member in the following year and 0 otherwise, a dummy coded 1 if the individual has been a member for up to one year at the time of observation and 0 otherwise, a dummy coded 1 if the individual has been a member for between one and two years at the time of observation and 0 otherwise, ..., and a dummy coded 1 if the individual has been member for at 
least 5 years or more at the time of observation and 0 otherwise. In equation form, this corresponds to:

$$
\begin{gathered}
Y_{i t}=\beta_{-5} M_{i t_{-5}}+\beta_{-4} M_{i t_{-4}}+\beta_{-3} M_{i t_{-3}}+\beta_{-2} M_{i t_{-2}}+\beta_{-1} M_{i t_{-1}}+\beta_{1} M_{i t_{1}}+\beta_{2} M_{i t_{2}} \\
+\beta_{3} M_{i t_{3}}+\beta_{4} M_{i t_{4}}+\beta_{5} M_{i t_{5}}+C_{i t}^{\prime} \gamma+v_{i}+\mu_{i t}, \\
\text { for } i=1,2, \ldots, N \text { and } t=1,2, \ldots, T
\end{gathered}
$$

We estimate the model using again fixed effects. In estimating these models, we choose as reference point the most distant time dummy ( 5 years or more before) from the transition we consider (joining a union). This reference point makes sense since it is the furthest from the two transitions, thus representing a good approximation to the control state not being yet influenced by future union involvement. The biggest issue of this analysis is the presence of large multicollinearity, consecutive dummy variables representing different moments in the membership trajectory that are highly correlated with each other. This produces an increase in the variance of the estimator by decreasing the statistical power at our disposal. There are ways to deal with the issue by imposing some restrictions on the dummy variables (e.g. Almon 1965), but they rely on assumptions we prefer to avoid making.

Besides providing a dynamic analysis instead of average effects, a dynamic model can lead to different conclusions in comparison to average treatment effects. In fact, the average treatment effects are mainly influenced by observations right before and right after the joining transition. Either because they leave after just one year of membership or because we do not observe them for long enough, many participants show only the observations right before and right after the transition we examine (cf. Table A6 in the Appendix). By being more numerous than those associated with longer durations, these observations are those influencing the most average treatment effects. By considering separately different moments of the trajectory, a dynamic analysis can show the appearance of trends that may become visible only after a certain duration of membership not experienced by most participants.

In both types of analyses (average and dynamic effects), we consider only the first spell of membership a wage-earner exhibits during her participations in the SHP. If union membership has durable effects (Gomez and Gunderson 2004; Hooghe 2003; Artz 2010), individuals that already have a past as members may still bear the effects of previous memberships. Focusing only on the first spell of membership also implies that we do not consider the act of leaving a union the opposite of becoming affiliated. To correct for heteroscedasticity and serial correlation at the individual level, in all models, we use cluster-robust standard errors, with the individual as the cluster unit. When the number of clusters is large enough (as it is our case), this type of standard errors has been shown to be the most robust and flexible option leading to unbiased test statistics (Petersen 2009). 
Figure 1

Average treatment effects of union membership on four dimensions of job satisfaction

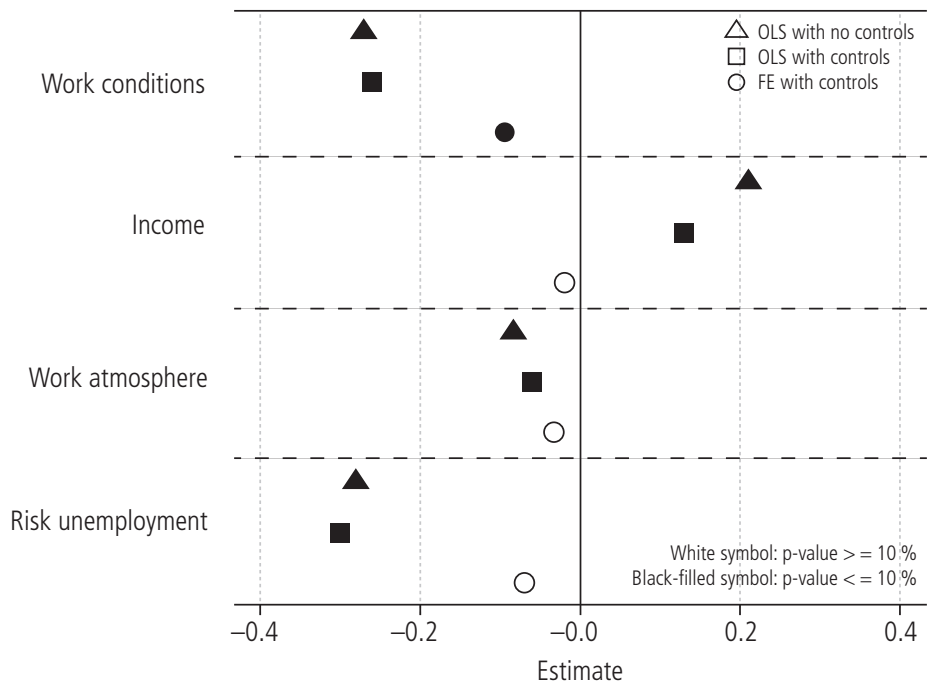

Abbreviations: "Work conditions" stands for "Satisfaction with working conditions"; "Income" stands for "Satisfaction with income"; "Work atmosphere" stands for "Satisfaction with work atmosphere"; "Risk unemployment" stands for "Self-evaluated risk of unemployment".

\section{Average treatment effects and relevant trends: Results}

Since we are only interested in the estimate associated with union membership, we plotted the average treatment effects' estimates in Figure 1. The figure presents standardized bounds $[-0.4,0.4]$. These make the magnitude of the estimates between distinct dependent variables visually comparable since they are all measured on a $0-10$ scale. Full models with the estimates of all control variables are available in Tables A2, A3, A4, and A5 in the Appendix.

Looking at the average observed difference between members and non-members in the "OLS without controls" model, we remark a pattern already highlighted in the existing literature. Union members are clearly disadvantaged when it comes to the satisfaction with working conditions $(-0.27, \mathrm{p}<0.001)$ and slightly less satisfied with their work atmosphere $(-0.083, \mathrm{p}<0.001)$ when compared to non-members. To the contrary, they show a higher satisfaction with income $(0.21, \mathrm{p}<0.001)$ and a lower feeling of being at risk of losing their job $(-0.28, \mathrm{p}<0.001)$.

The differences between members and non-members decrease after including a set of observed controls in the "OLS with controls" models but remain still signifi- 
Figure 2

Dynamic fixed effects of union membership on four dimensions of job satisfaction
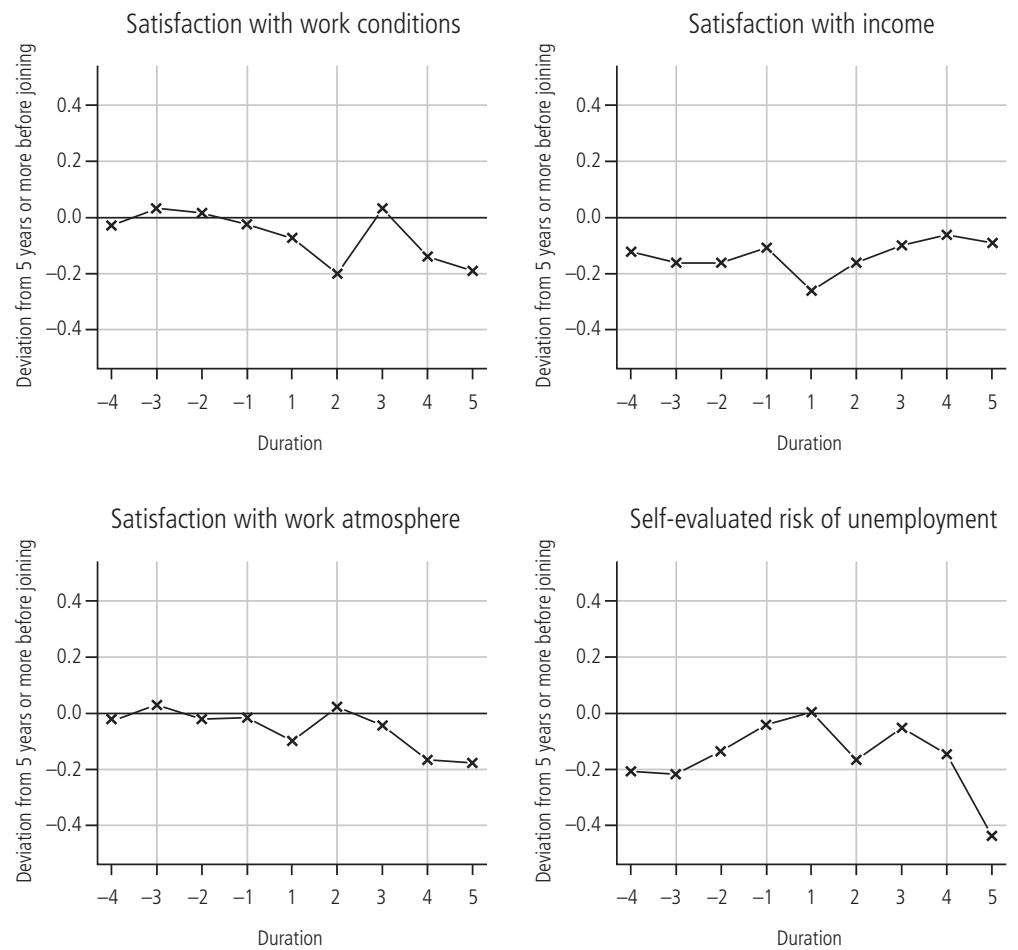

cant. Unions members are still less satisfied with their working conditions $(-0.26$, $\mathrm{p}<0.001)$ and work atmosphere $(-0.060, \mathrm{p}<0.05)$ and advantaged in terms of income $(0.13, \mathrm{p}<0.001)$ and self-evaluated unemployment $(-0.30, \mathrm{p}<0.001)$ perception.

The estimates and their significance decrease much more when controlling for all time-invariant omitted variables in the "Fixed effects with controls" models. Only the coefficient of union membership associated with the satisfaction with working conditions $(-0.094, \mathrm{p}<0.05)$ remains barely significant, while the differences in the other three dimensions of job satisfaction turn out to be related to selection effects.

Moving to the dynamic fixed effects analysis, once again, we provide a plot of the estimates of interest associated with union membership in Figure 2. Full regression estimates with control variables are available in Table A7 in the Appendix. In addition to these estimates, we provide specific significance tests when we remark clear trends that do not have 5 years or more before joining as reference point. 
Looking at the dynamic effects of union membership on the satisfaction with working conditions, we see that the level of satisfaction decreases from 3 years before joining on with a decline that becomes more pronounced in the first two years of membership, even though the trend is significant only at the $10 \%$ level because of the high multicollinearity that affects the different dummies (trend $-3 \rightarrow 2[-0.23$, $\mathrm{p}<0.10]$ ). The level of satisfaction recovers in the third year of membership (trend $2 \rightarrow 3[0.23, \mathrm{p}<0.10])$. We then observe a decrease in the last two years, which is however not even close to be significant and may be a statistical incident related to the low number of individuals observed as members for long enough (cf. Table A6 in the Appendix).

Looking at the satisfaction with income, we remark a clear drop only in the years representing the transition to union membership (trend $-1 \rightarrow 1[-0.16$, $\mathrm{p}<0.5])$. The level of income satisfaction then fully recovers until the fourth year of membership (trend $1 \rightarrow 4[0.20, \mathrm{p}<0.10]$ ).

Focusing on the way the work atmosphere is perceived, no significant trend (not even at the $10 \%$ level) is observable.

Turning our attention to the self-evaluated risk of unemployment, we remark a linear increase in the pre-membership phase that starts three years before joining and peaks during the first year of membership (trend $-3 \rightarrow 1[0.22, \mathrm{p}<0.10]$ ). Job insecurity clearly decreases during the membership phase (trend $1 \rightarrow 5[-0.44$, $\mathrm{p}<0.05])$.

\section{Unobservable and longitudinal attitudinal processes: Discussion}

The results of the previous section allow us to shed new light on the link between union membership and job satisfaction. At a descriptive level, we have confirmed that union members are less satisfied with the internal dimensions of their job (working conditions and work atmosphere) and have a more positive perception of external outcomes (income and job security) when compared to non-members even in a coordinated market economy like Switzerland. The dissatisfaction in terms of working conditions is however much stronger than the one associated with the work atmosphere, which implies that it is objective work arrangements rather than relational aspects between colleagues that distinguish union from non-union jobs. In addition, the advantage of union members in terms of self-evaluated risk of unemployment and income satisfaction seems lower than one may expect considering the much stronger job protection and income differentials they enjoy. For instance, in our Swiss sample, union members declare an average gross yearly income of 81823 Swiss Francs, ${ }^{3}$ compared to 63864 Swiss Francs for non-members.

3 The amount refers to individual employment income. Although exchange rates vary across time and we use panel data, the exchange rate between the Swiss Franc and the US dollar has fluctu- 
Trying to understand whether these differences are the consequence of a selection effect related to different professional circumstances and/or individual personality traits between non-members and members or causal effects of union membership, we started by including a set of observed controls supposed to capture relevant omitted variables. The results we obtained are very similar to those known in the existing literature, with a small decrease in the magnitude of the estimates, which however remain still highly significant. The decrease in terms of magnitude and significance becomes much more important when exploiting the advantages of panel data. Only the disadvantage in terms of satisfaction with working conditions of union members remains significant at the $5 \%$ level. The observed differences in terms of job satisfaction dimensions between members and non-members are hence to a large extent, if not exclusively, the consequence of a selection effect. Only a small part of self-selection is related to observed control variables. The largest part of the differential is explained by time-invariant unobserved heterogeneity between members and non-members. When the outcome variable is an attitudinal dimension such as job satisfaction, causality should be inferred very carefully with crosssectional models. Attitudinal dimensions are in general determined by a myriad of factors, many of which are potentially unobservable or difficult to measure. Repeated observations over the same individuals provide much higher leverage to distinguish between selection and causal effects.

Going beyond average effects, we were able to remark that union membership and three dimensions of job satisfaction entertain a dynamic relationship. The only exception is the perception of the work atmosphere, not showing any significant trends and being also the outcome with the lowest association with union membership at a descriptive level. This implies that unions do have an impact on job satisfaction dimensions, but not all aspects of an individual's job are affected. Since we do not observe dynamic variations neither in the pre- nor in the post-membership phase, changes in relational dynamics do not seem to be a relevant reason to join a union and they are not affected by the membership experience. There are professional domains that are part of the scope of union activities (working conditions, income, job security), while other ones such as the relationships with colleagues are not seen among union priorities by prospective joiners and do not change importantly as a consequence of the union membership experience.

Regarding the other three dimensions of job satisfaction, all three show a negative trend peaking in the first year of membership. The satisfaction with working conditions and income exhibit a clear decrease between the year before joining and the first year of membership. This signals the likely presence of time-varying reversed causality. A deterioration in terms of working conditions and/or income

ated around 1:1 during the 1999-2017 period examined in these analyses (U.S. Dollar to Swiss Franc Spot Exchange Rates for 1975 to 2019 from the Bank of England. Accessed December 17, 2019. https://www.poundsterlinglive.com/bank-of-england-spot/historical-spot-exchange-rates/ usd/USD-to-CHF). 
represents the main reason to join a union, probably expecting a positive impact of unions in these dimensions. Despite their weakened role as regulatory agents of the labor market, these findings are consistent with the idea that wage-earners still see unions as a relevant agent capable of having positive effects in certain professional dimensions, especially when sudden issues are experienced. The same is true for the self-evaluated risk of unemployment, but the feeling of job insecurity starts already three years before joining and increases linearly until the first year of membership. Therefore, a decreasing job security may lead to the choice to join a union, but that happens more gradually when compared to the satisfaction with working conditions or income. This gradual attitudinal process is unlikely to be related to strong and sudden variations at the workplace but may be linked to general trends in the labor market such as liberalization and flexibilization that slowly become more relevant for a wage-earner and that culminate in the act of joining a union, seeking protection.

Does job satisfaction recover after joining? The attitudinal evolution after joining a union implies that unions are still able to provide significant benefits in all three dimensions of job satisfaction. Satisfaction with working conditions and income recover at levels similar to the situation before experiencing issues at the workplace, while the feeling of the risk of unemployment decreases at levels even lower than the moment at which a feeling of insecurity started. We were not able to detect such positive trends in average treatment effects because these trends become noticeable only after a certain duration of membership. Panel data are necessary in order to be able to distinguish between different membership durations (unless one has the rare information about the duration of membership with cross-sectional data) and to detect long-term trends. A look at Table A6 in the Appendix shows that most membership episodes we detect do not go beyond the first year of membership either because individuals leave unions or because we stop observing them in the survey. These individuals are those influencing the most the negative average treatment effects since the drop in job satisfaction is most obvious right after becoming a member. The positive effects of union membership appear only from the second year of membership on and potentially increase even more afterwards. It is also possible that short-term members may be those with the most precarious working situations, not allowing them to remain members for long enough to experience the positive effects that long-term members exhibit.

Starting this paper with the paradoxical lower job satisfaction of union members when compared to non-members, we were able to show that the enigma does no longer appear as such when switching from a cross-sectional to a longitudinal perspective. Working with panel data turns out to be crucial to be able to partial 
out selection effects related to unobserved heterogeneity. When all time-invariant unobserved omitted factors are controlled for, the differentials in terms of job satisfaction between union members and non-members become very small or irrelevant. When the dependent variable is an attitudinal dimension, being hence potentially influenced by many unobservable factors, causality should be inferred with much caution when working with cross-sectional data. Panel data are indispensable to deal with endogeneity issues.

In addition to allowing partialling out the effect of unobserved heterogeneity, panel data make it possible to observe relationships in a new light. Adding a longitudinal dimension shows that job satisfaction varies dynamically. Decreases in job satisfaction appear in general right before becoming affiliated, revealing that a deterioration in job satisfaction is probably the main reason behind the choice to join a union. Therefore, unions are still seen as an actor capable of providing important benefits in certain job-related dimensions (working conditions, income, job security) but not in other ones outside of the scope of their responsibilities (the relationships with colleagues). Looking at the improvement in terms of satisfaction and job security that becomes visible after a certain number of years of membership, unions appear to be still able to exert a consequential influence on the well-being of their members.

The results sketched out above concern only the Swiss case and the link between union membership and job satisfaction. The fact that our results are similar to those found in liberal market economies implies that general trends such as the liberalization and the tertiarization of the labor market affect union members in different institutional contexts the same way. In addition, the general implications of our empirical findings (the importance of unobserved heterogeneity and of a dynamic dimension) are potentially relevant in various types of relationships examined so far only through cross-sectional data.

\section{References}

Akerlof, George A., Andrew K. Rose, Janet L. Yellen, Laurence Ball, and Robert E. Hall. 1988. Job Switching and Job Satisfaction in the U.S. Labor Market. Brookings Papers on Economic Activity 1988(2): 495-594.

Allen, Steven G. 1984. Trade Unions, Absenteeism, and Exit-Voice. ILR Review 37(3): 331-345.

Almon, Shirley. 1965. The Distributed Lag between Capital Appropriations and Expenditures. Econometrica 33(1): 178-196.

Artz, Benjamin. 2010. The Impact of Union Experience on Job Satisfaction. Industrial Relations: A Journal of Economy and Society 49(3): 387-405.

Avdagic, Sabina, and Lucio Baccaro. 2016. The Future of Employment Relations in Advanced Capitalism: Inexorable Decline? Pp. 701-725 in The Oxford Handbook of Employment Relations, edited by Adrian Wilkinson, Geoffrey Wood, and Richard Deeg. Oxford, US: Oxford University Press. 
Baccaro, Lucio, Kerstin Hamann, and Lowell Turner. 2003. The Politics of Labour Movement Revitalization: The Need for a Revitalized Perspective. European Journal of Industrial Relations 9(1): 119-133.

Baccaro, Lucio, and Chris Howell. 2017. Trajectories of Neoliberal Transformation: European Industrial Relations since the 1970s. Cambridge, UK: Cambridge University Press.

Bender, Keith A., and Peter J. Sloane. 1998. Job Satisfaction, Trade Unions, and Exit-Voice Revisited. ILR Review 51(2): 222-240.

Berger, Chris J., Craig A. Olson, and John W. Boudreau. 1983. Effects of Unions on Job Satisfaction: The Role of Work-Related Values and Perceived Rewards. Organizational Behavior and Human Performance 32(3): 289-324.

Borjas, George. 1979. Job Satisfaction, Wages, and Unions. Journal of Human Resources 14(1): 21-40.

Brochu, Pierre, and Louis-Philippe Morin. 2012. Union Membership and Perceived Job Insecurity: Thirty Years of Evidence from the American General Social Survey. ILR Review 65(2): 263-285.

Bryson, Alex, Lorenzo Cappellari, and Claudio Lucifora. 2004. Does Union Membership Really Reduce Job Satisfaction? British Journal of Industrial Relations 42(3): 439-459.

Freeman, Richard B. 1978. Job Satisfaction as an Economic Variable. The American Economic Review 68(2): 135-141.

Freeman, Richard B. 1980. The Exit-Voice Tradeoff in the Labor Market: Unionism, Job Tenure, Quits and Separations. Quarterly Journal of Economics 94(4): 643-673.

Freeman, Richard B., and James L. Medoff. 1984. What Do Unions Do? New York: Basic Books.

Gomez, Rafael, and Morley Gunderson. 2004. The Experience-Good Model of Union Membership. Pp. 92-114 in The Changing Role of Unions: New Forms of Representation, edited by Phanindra V. Wunnava. Armonk, NY: M.E. Sharpe.

Gordon, Michael E., and Angelo S. Denisi. 1995. A Re-Examination of the Relationship between Union Membership and Job Satisfaction. ILR Review 48(2): 222-236.

Hall, Peter A., and David Soskice. 2001. Varieties of Capitalism: The Institutional Foundations of Comparative Advantage. Oxford, US: Oxford University Press.

Hammer, Tove Helland, and Ariel Avgar. 2005. The Impact of Unions on Job Satisfaction, Organizational Commitment, and Turnover. Journal of Labor Research 26(2): 241-266.

Hersch, Joni, and Joe A. Stone. 1990. Is Union Job Dissatisfaction Real? The Journal of Human Resources 25(4): 736-751.

Herzberg, Frederick. 1966. Work and the Nature of Man. New York: World Publishing Company.

Heywood, John S., W. S. Siebert, and Xiangdong Wei. 2002. Worker Sorting and Job Satisfaction: The Case of Union and Government Jobs. ILR Review 55(4): 595-609.

Hirschman, Albert O. 1970. Exit, Voice, and Loyalty: Responses to Decline in Firms, Organizations, and States. Cambridge, US: Harvard University Press.

Hooghe, Marc. 2003. Participation in Voluntary Associations and Value Indicators: The Effect of Current and Previous Participation Experiences. Nonprofit and Voluntary Sector Quarterly 32(1): 47-69.

Hulin, Charles L., Mary Roznowski, and Donna Hachiya. 1985. Alternative Opportunities and Withdrawal Decisions: Empirical and Theoretical Discrepancies and an Integration. Psychological Bulletin 97(2): 233-250.

Kochan, Thomas A., and David E. Helfman. 1981. The Effects of Collective Bargaining on Economic and Behavioral Job Outcomes. Working paper 1181-81. Massachusetts Institute of Technology (MIT), Sloan School of Management. https://econpapers.repec.org/paper/mitsloanp/1978.htm (28.02.2020).

Lehmbruch, Gerhard. 1993. Consociational Democracy and Corporatism in Switzerland. Publius: The Journal of Federalism 23(2): 43-60. 
Leigh, Duane E. 1986. Union Preferences, Job Satisfaction, and the Union-Voice Hypothesis. Industrial Relations: A Journal of Economy and Society 25(1): 65-71.

Lijphart, Arend. 1998. Patterns of Democracy: Government Forms and Performance in Thirty-Six Countries. New Haven: Yale University Press.

Lincoln, James R., and Joan N. Boothe. 1993. Unions and Work Attitudes in the United States and Japan. Industrial Relations: A Journal of Economy and Society 32(2): 159-187.

Lu, Hong, Alison E. While, and K. Louise Barriball. 2005. Job Satisfaction among Nurses: A Literature Review. International Journal of Nursing Studies 42(2): 211-227.

Mangione, T. W., and Robert P. Quinn. 1975. Job Satisfaction, Counterproductive Behavior, and Drug Use at Work. The Journal of Applied Psychology 60(1): 114-116.

Maslow, Abraham Harold. 1970. Motivation and Personality. New York: Harper \& Row.

McEvoy, Glenn, and Wayne F. Cascio. 1985. Strategies for Reducing Employee Turnover: A Meta-Analysis. Journal of Applied Psychology 70(2) 342-353.

Meng, Ronald. 1990. The Relationship between Unions and Job Satisfaction. Applied Economics 22(12): $1635-1648$.

Miller, Paul W. 1990. Trade Unions and Job Satisfaction. Australian Economic Papers 29(55): 226-248.

Pencavel, John. 2009. How Successful Have Trade Unions Been? A Utility-Based Indicator of Union Well-Being. ILR Review 62(2): 147-156.

Petersen, Mitchell A. 2009. Estimating Standard Errors in Finance Panel Data Sets: Comparing Approaches. The Review of Financial Studies 22(1): 435-480.

Pfeffer, Jeffrey, and Alison Davis-Blake. 1990. Unions and Job Satisfaction: An Alternative View. Work and Occupations 17(3): 259-283.

Powdthavee, Nattavudh. 2011. Anticipation, Free-Rider Problems, and Adaptation to Trade Unions: Re-Examining the Curious Case of Dissatisfied Union Members. ILR Review 64(5): 1000-1019.

Rees, Daniel I. 1991. Grievance Procedure Strength and Teacher Quits. ILR Review 45(1): 31-43.

Renaud, Stephane. 2002. Rethinking the Union Membership/Job Satisfaction Relationship: Some Empirical Evidence in Canada. International Journal of Manpower 23(2): 137-150.

Schwochau, Susan. 1987. Union Effects on Job Attitudes. ILR Review 40(2): 209-224.

Streeck, Wolfgang, and Anke Hassel. 2003. Trade Unions as Political Actors. Pp. 335-365 in International Handbook of Trade Unions, edited by John T. Addison and Claus Schnabel. Cheltenham: Elgar.

Wooldridge, Jeffrey M. 2010. Econometric Analysis of Cross Section and Panel Data. Cambridge, US: The MIT Press.

Worrall, John D., and Richard J. Butler. 1983. Health Conditions and Job Hazards: Union and Nonunion Jobs. Journal of Labor Research 4(4): 339-347. 


\section{Appendix}

Table A1 Descriptive statistics on all variables

\begin{tabular}{|c|c|c|c|c|c|}
\hline & Min & Max & Mean & $\begin{array}{l}\text { Standard } \\
\text { deviation }\end{array}$ & Observations \\
\hline Union membership & 0 & 1 & .203249 & .4024 & 56325 \\
\hline Working conditions satisfaction & 0 & 10 & 7.789208 & 1.6740 & 56207 \\
\hline Income satisfaction & 0 & 10 & 7.258107 & 1.9649 & 56124 \\
\hline Work atmosphere & 0 & 10 & 8.423477 & 1.4770 & 54572 \\
\hline Risk of unemployment & 0 & 10 & 1.93863 & 2.4492 & 55467 \\
\hline Gender male & 0 & 1 & .4782423 & .4995 & 56325 \\
\hline Age 25 years or less & 0 & 1 & .1609616 & .3674 & 56324 \\
\hline Age $26-65$ years & 0 & 1 & .8236986 & .3810 & 56324 \\
\hline Age 66 years or more & 0 & 1 & .0153398 & .1229 & 56324 \\
\hline Education primary & 0 & 1 & .165273 & .3714 & 56325 \\
\hline Education secondary & 0 & 1 & .659352 & .4739 & 56325 \\
\hline Education tertiary & 0 & 1 & .1753751 & .3802 & 56325 \\
\hline Nationality foreigner & 0 & 1 & .1121666 & .3155 & 56318 \\
\hline Region Lake Geneva & 0 & 1 & .1727297 & .3780 & 56325 \\
\hline Region Middleland & 0 & 1 & .2572392 & .4371 & 56325 \\
\hline Region Northwest & 0 & 1 & .1462938 & .3534 & 56325 \\
\hline Region Zurich & 0 & 1 & .1717532 & .3771 & 56325 \\
\hline Region East & 0 & 1 & .1234443 & .3289 & 56325 \\
\hline Region Central & 0 & 1 & .096174 & .2948 & 56325 \\
\hline Region Ticino & 0 & 1 & .0323657 & .1769 & 56325 \\
\hline Canton Latin & 0 & 1 & .2993342 & .4579 & 56325 \\
\hline Marital status couple & 0 & 1 & .5431448 & .4981 & 56322 \\
\hline 1999 & 0 & 1 & .073715 & .2613 & 56325 \\
\hline 2000 & 0 & 1 & .0624945 & .2420 & 56325 \\
\hline 2001 & 0 & 1 & .0571682 & .2321 & 56325 \\
\hline 2002 & 0 & 1 & .0523391 & .2227 & 56325 \\
\hline 2003 & 0 & 1 & .0504749 & .2189 & 56325 \\
\hline 2004 & 0 & 1 & .0809232 & .2727 & 56325 \\
\hline 2005 & 0 & 1 & .0655126 & .2474 & 56325 \\
\hline 2006 & 0 & 1 & .060435 & .2382 & 56325 \\
\hline 2007 & 0 & 1 & .0699689 & .2550 & 56325 \\
\hline 2008 & 0 & 1 & .0702352 & .2555 & 56325 \\
\hline 2009 & 0 & 1 & .0715135 & .2576 & 56325 \\
\hline 2011 & 0 & 1 & .075668 & .2644 & 56325 \\
\hline 2014 & 0 & 1 & .1187572 & .3235 & 56325 \\
\hline 2017 & 0 & 1 & .0907945 & .2873 & 56325 \\
\hline
\end{tabular}

Source: Swiss Household Panel (SHP) 
Table A2 Average treatment effect of union membership on the satisfaction with working conditions

\begin{tabular}{|c|c|c|c|}
\hline & OLS without controls & OLS with controls & FE with controls \\
\hline Union member & $-0.27^{* * *}$ & $-0.26^{* * *}$ & $-0.094^{*}$ \\
\hline Gender male & & $-0.12^{* * *}$ & 0 \\
\hline \multicolumn{4}{|l|}{ Age (ref. 0-25 years) } \\
\hline Age $26-65$ years & & $-0.15^{* * *}$ & -0.071 \\
\hline Age 66 years or more & & $0.91 * * *$ & $0.47^{* * *}$ \\
\hline \multicolumn{4}{|l|}{ Education (ref. primary) } \\
\hline Education secondary & & $-0.17^{* * *}$ & $-0.35^{* * *}$ \\
\hline Education tertiary & & $-0.12^{* *}$ & $-0.27^{* *}$ \\
\hline Nationality foreigner & & $-0.34^{* * *}$ & 0.11 \\
\hline \multicolumn{4}{|l|}{ Region (ref. Lake Geneva) } \\
\hline Region Middleland & & $0.20 * * *$ & 0.097 \\
\hline Region Northwest & & $0.27^{* * *}$ & 0.19 \\
\hline Region Zurich & & $0.21 * * *$ & -0.12 \\
\hline Region East & & $0.34^{* * *}$ & 0.056 \\
\hline Region Central & & $0.38^{* * *}$ & 0.11 \\
\hline Region Ticino & & $0.14+$ & -0.43 \\
\hline Marital status couple & & $0.22^{* * *}$ & $0.12^{* *}$ \\
\hline \multicolumn{4}{|l|}{ Year (ref. 1999) } \\
\hline 2000 & & 0.056 & 0.054 \\
\hline 2001 & & $0.096^{*}$ & $0.076^{*}$ \\
\hline 2002 & & 0.046 & 0.036 \\
\hline 2003 & & $0.12^{* *}$ & $0.088^{*}$ \\
\hline 2004 & & 0.048 & -0.024 \\
\hline 2005 & & 0.026 & -0.035 \\
\hline 2006 & & -0.067 & $-0.14^{\star *}$ \\
\hline 2007 & & $-0.088^{*}$ & $-0.14^{* *}$ \\
\hline 2008 & & $-0.081^{*}$ & $-0.14^{* *}$ \\
\hline 2009 & & $-0.086^{*}$ & $-0.17^{\star * *}$ \\
\hline 2011 & & $-0.063+$ & $-0.15^{\star * *}$ \\
\hline 2014 & & -0.000 & $-0.15^{* *}$ \\
\hline 2017 & & $-0.12^{* *}$ & $-0.21^{* * *}$ \\
\hline Individuals & 14933 & 14929 & 14929 \\
\hline Observations & 49988 & 49977 & 49977 \\
\hline
\end{tabular}

Note: significance levels: $+p<0.10 .{ }^{*} p<0.05 .{ }^{* *} p<0.01 .{ }^{* * *} p<0.001$. Source: Swiss Household Panel (SHP) 
Table A3 Average treatment effect of union membership on the satisfaction with income

\begin{tabular}{|c|c|c|c|}
\hline & OLS without controls & OLS with controls & FE with controls \\
\hline Union member & $0.21^{* * *}$ & $0.13^{* * *}$ & -0.019 \\
\hline Gender male & & 0.033 & 0 \\
\hline \multicolumn{4}{|l|}{ Age (ref. $0-25$ years) } \\
\hline Age $26-65$ years & & $0.21 * * *$ & 0.11 \\
\hline Age 66 years or more & & $1.13^{* * *}$ & $0.64^{* \star *}$ \\
\hline \multicolumn{4}{|l|}{ Education (ref. primary) } \\
\hline Education secondary & & -0.059 & $-0.65^{* * *}$ \\
\hline Education tertiary & & $0.17^{* *}$ & $-0.49 * * *$ \\
\hline Nationality foreigner & & $-0.45^{* * *}$ & 0.078 \\
\hline \multicolumn{4}{|l|}{ Region (ref. Lake Geneva) } \\
\hline Region Middleland & & $0.23 * * *$ & -0.13 \\
\hline Region Northwest & & $0.32^{* * *}$ & 0.025 \\
\hline Region Zurich & & $0.25^{* * *}$ & -0.068 \\
\hline Region East & & $0.35^{* * *}$ & 0.15 \\
\hline Region Central & & $0.40^{* * *}$ & 0.19 \\
\hline Region Ticino & & $0.18+$ & 0.017 \\
\hline Marital status couple & & $0.29 * * *$ & $0.095^{*}$ \\
\hline \multicolumn{4}{|l|}{ Year (ref. 1999) } \\
\hline 2000 & & $-0.13^{* *}$ & $-0.12^{* *}$ \\
\hline 2001 & & -0.033 & -0.017 \\
\hline 2002 & & -0.030 & -0.016 \\
\hline 2003 & & 0.015 & 0.017 \\
\hline 2004 & & -0.064 & -0.036 \\
\hline 2005 & & $-0.11^{*}$ & -0.066 \\
\hline 2006 & & $-0.19 * * *$ & $-0.12^{*}$ \\
\hline 2007 & & $-0.14^{* *}$ & -0.045 \\
\hline 2008 & & $-0.10^{*}$ & -0.011 \\
\hline 2009 & & $-0.082+$ & -0.007 \\
\hline 2011 & & $-0.076+$ & 0.039 \\
\hline 2014 & & -0.049 & $0.091+$ \\
\hline 2017 & & $-0.17^{* * *}$ & 0.046 \\
\hline Individuals & 14892 & 14888 & 14888 \\
\hline Observations & 49911 & 49900 & 49900 \\
\hline
\end{tabular}

Note: significance levels: $+p<0.10 .{ }^{*} p<0.05 .{ }^{* *} p<0.01 .{ }^{* * *} p<0.001$. Source: Swiss Household Panel (SHP) 
Table A4 Average treatment effect of union membership on the satisfaction with the work atmosphere

\begin{tabular}{|c|c|c|c|}
\hline & OLS without controls & OLS with controls & FE with controls \\
\hline Union member & $-0.083^{* * *}$ & $-0.060^{*}$ & -0.032 \\
\hline Gender male & & $-0.10^{* * *}$ & 0 \\
\hline \multicolumn{4}{|l|}{ Age (ref. $0-25$ years) } \\
\hline Age $26-65$ years & & $-0.16^{* * *}$ & $-0.11^{*}$ \\
\hline Age 66 years or more & & $0.60^{* * *}$ & $0.28^{* *}$ \\
\hline \multicolumn{4}{|l|}{ Education (ref. primary) } \\
\hline Education secondary & & $-0.072^{\star}$ & -0.063 \\
\hline Education tertiary & & $-0.18^{* * *}$ & -0.029 \\
\hline Nationality foreigner & & $-0.28^{* * *}$ & 0.032 \\
\hline \multicolumn{4}{|l|}{ Region (ref. Lake Geneva) } \\
\hline Region Middleland & & $0.25^{* * *}$ & 0.051 \\
\hline Region Northwest & & $0.38^{* * *}$ & 0.19 \\
\hline Region Zurich & & $0.29 * * *$ & -0.034 \\
\hline Region East & & $0.41^{* * *}$ & 0.29 \\
\hline Region Central & & $0.39 * * *$ & 0.30 \\
\hline Region Ticino & & 0.082 & -0.087 \\
\hline Marital status couple & & $0.11^{* * *}$ & -0.016 \\
\hline \multicolumn{4}{|l|}{ Year (ref. 1999) } \\
\hline 2000 & & -0.008 & 0.010 \\
\hline 2001 & & -0.023 & -0.0018 \\
\hline 2002 & & $-0.068+$ & $-0.061+$ \\
\hline 2003 & & $-0.11^{* *}$ & $-0.10^{* *}$ \\
\hline 2004 & & $-0.066^{*}$ & $-0.100^{* *}$ \\
\hline 2005 & & $-0.12^{* * *}$ & $-0.15^{* * *}$ \\
\hline 2006 & & $-0.24^{* * *}$ & $-0.28^{* * *}$ \\
\hline 2007 & & $-0.22^{* * *}$ & $-0.21^{* * *}$ \\
\hline 2008 & & $-0.23^{* * *}$ & $-0.24^{* * *}$ \\
\hline 2009 & & $-0.27^{* * *}$ & $-0.31^{* * *}$ \\
\hline 2011 & & $-0.24^{* * *}$ & $-0.28^{* * *}$ \\
\hline 2014 & & $-0.16^{* * *}$ & $-0.29 * * *$ \\
\hline 2017 & & $-0.30^{* * *}$ & $-0.38^{* * *}$ \\
\hline Individuals & 14602 & 14598 & 14598 \\
\hline Observations & 48467 & 48456 & 48456 \\
\hline
\end{tabular}

Note: significance levels: $+p<0.10 .{ }^{*} p<0.05 .{ }^{* *} p<0.01 .{ }^{* * *} p<0.001$. Source: Swiss Household Panel (SHP) 
Table A5 Average treatment effect of union membership on the selfevaluated risk of unemployment

\begin{tabular}{|c|c|c|c|}
\hline & OLS without controls & OLS with controls & FE with controls \\
\hline Union member & $-0.28^{* * *}$ & $-0.30^{* * *}$ & -0.069 \\
\hline Gender male & & $0.059+$ & 0 \\
\hline \multicolumn{4}{|l|}{ Age (ref. $0-25$ years) } \\
\hline Age $26-65$ years & & $0.29 * * *$ & -0.095 \\
\hline Age 66 years or more & & $-0.52^{* * *}$ & $-0.42^{*}$ \\
\hline \multicolumn{4}{|l|}{ Education (ref. primary) } \\
\hline Education secondary & & $0.28^{* * *}$ & $0.78^{* * *}$ \\
\hline Education tertiary & & 0.025 & $0.66^{* * *}$ \\
\hline Nationality foreigner & & $0.48^{* * *}$ & -0.40 \\
\hline \multicolumn{4}{|l|}{ Region (ref. Lake Geneva) } \\
\hline Region Middleland & & $-0.22^{* * *}$ & -0.13 \\
\hline Region Northwest & & $-0.26 * * *$ & $-0.65^{*}$ \\
\hline Region Zurich & & $-0.13^{*}$ & -0.23 \\
\hline Region East & & $-0.45^{* * *}$ & $-0.53+$ \\
\hline Region Central & & $-0.40 * * *$ & $-0.46+$ \\
\hline Region Ticino & & $-0.25^{*}$ & -0.18 \\
\hline Marital status couple & & $-0.21^{* * *}$ & -0.057 \\
\hline \multicolumn{4}{|l|}{ Year (ref. 1999) } \\
\hline 2000 & & $-0.38^{* * *}$ & $-0.30^{* * *}$ \\
\hline 2001 & & $-0.19 * * *$ & $-0.12^{*}$ \\
\hline 2002 & & 0.0066 & 0.073 \\
\hline 2003 & & $0.18^{* *}$ & $0.23^{* * *}$ \\
\hline 2004 & & $0.29 * * *$ & $0.45^{* * *}$ \\
\hline 2005 & & $0.40^{* * *}$ & $0.51^{* * *}$ \\
\hline 2006 & & $0.31^{* * *}$ & $0.43^{* * *}$ \\
\hline 2007 & & $0.17^{* *}$ & $0.27^{* * *}$ \\
\hline 2008 & & $0.25 * * *$ & $0.35^{* * *}$ \\
\hline 2009 & & $0.38^{* * *}$ & $0.52^{* * *}$ \\
\hline 2011 & & $0.25^{* * *}$ & $0.35^{* * *}$ \\
\hline 2014 & & $0.096+$ & $0.23^{* * *}$ \\
\hline 2017 & & $0.25^{* * *}$ & $0.39^{* * *}$ \\
\hline Individuals & 14799 & 14795 & 14795 \\
\hline Observations & 49299 & 49289 & 49289 \\
\hline
\end{tabular}

Note: significance levels: $+p<0.10 .{ }^{*} p<0.05 .{ }^{* *} p<0.01 .{ }^{* * *} p<0.001$. Source: Swiss Household Panel (SHP) 
Table A6 Descriptive statistics related to the number of observations contributing to the dynamic analysis

\begin{tabular}{lrr}
\hline Duration & Absolute frequency & Relative frequency \\
\hline 5 years before or more & 1494 & 21.41 \\
4 years before & 306 & 4.39 \\
3 years before & 722 & 10.35 \\
2 years before & 646 & 9.26 \\
1year before & 1024 & 14.67 \\
1 year after & 1396 & 20.01 \\
2 years after & 357 & 5.12 \\
3 years after & 226 & 3.24 \\
4 years after & 215 & 3.08 \\
5 years after or more & 592 & 8.48 \\
\hline
\end{tabular}

Source: Swiss Household Panel (SHP)

Table A7 Dynamic fixed effects of union membership on four dimensions of job satisfaction

\begin{tabular}{lcccc}
\hline & $\begin{array}{c}\text { Working } \\
\text { conditions }\end{array}$ & Income & $\begin{array}{c}\text { Work } \\
\text { atmosphere }\end{array}$ & $\begin{array}{c}\text { Risk of } \\
\text { unemployment }\end{array}$ \\
\hline Duration (ref. 5 years before or more) & & & & \\
$\quad 4$ years before & -0.029 & -0.12 & -0.026 & -0.21 \\
3 years before & 0.033 & -0.16 & 0.026 & -0.22 \\
2 years before & 0.016 & -0.16 & -0.017 & -0.14 \\
1 year before & -0.025 & -0.11 & -0.018 & -0.044 \\
1 year after & -0.073 & $-0.26^{*}$ & -0.10 & -0.00051 \\
2 years after & -0.20 & -0.16 & 0.017 & -0.17 \\
3 years after & 0.032 & -0.10 & -0.045 & -0.056 \\
4 years after & -0.14 & -0.063 & -0.17 & -0.15 \\
5 years after & -0.19 & -0.090 & -0.18 & -0.44 \\
Gender male & 0 & 0 & 0 & 0 \\
Age (ref. 0-25 years) & & & & \\
Age 26-65 years & -0.18 & 0.046 & -0.11 & -0.019 \\
Age 66 years or more & -0.43 & -0.36 & 0.12 & -0.73 \\
Education (ref. primary) & & & & \\
Education secondary & -0.26 & $-0.74^{* * *}$ & 0.19 & $1.07^{* * *}$ \\
Education tertiary & -0.061 & -0.33 & 0.14 & $0.73^{*}$ \\
Nationality foreigner & -0.13 & -0.19 & 0.46 & -0.48 \\
\hline
\end{tabular}


Continuation of table A7.

\begin{tabular}{lcccc}
\hline & $\begin{array}{c}\text { Working } \\
\text { conditions }\end{array}$ & Income & $\begin{array}{c}\text { Work } \\
\text { atmosphere }\end{array}$ & $\begin{array}{c}\text { Risk of } \\
\text { unemployment }\end{array}$ \\
\hline Region (ref. Lake Geneva) & & & & \\
Region Middleland & 0.43 & 0.17 & 0.45 & -0.54 \\
Region Northwest & 0.99 & 0.30 & 0.88 & -0.052 \\
Region Zurich & $1.11+$ & 0.94 & $1.04+$ & -1.06 \\
Region East & $1.14+$ & 0.81 & $1.03+$ & -0.88 \\
Region Central & $1.22^{*}$ & 0.82 & $1.19^{*}$ & -0.48 \\
Region Ticino & $-1.27^{* *}$ & $3.32^{* * *}$ & -0.50 & -0.92 \\
Marital status couple & $0.23^{*}$ & 0.15 & -0.026 & -0.035 \\
Year (ref. 1999) & & & & \\
2000 & $0.14+$ & 0.060 & 0.019 & $-0.27^{*}$ \\
2001 & 0.051 & 0.10 & 0.012 & -0.11 \\
2002 & -0.0017 & 0.041 & -0.038 & -0.12 \\
2003 & 0.13 & 0.079 & -0.035 & 0.086 \\
2004 & -0.041 & 0.17 & 0.031 & $0.54^{* *}$ \\
2005 & 0.025 & 0.19 & -0.021 & $0.49^{*}$ \\
2006 & -0.11 & 0.13 & -0.16 & 0.33 \\
2007 & -0.25 & 0.14 & -0.16 & 0.27 \\
2008 & -0.18 & 0.27 & $-0.28+$ & 0.35 \\
2009 & $-0.28+$ & 0.21 & $-0.27+$ & 0.28 \\
2011 & -0.063 & 0.25 & -0.26 & 0.28 \\
2014 & -0.081 & $0.39+$ & -0.17 & 0.020 \\
2017 & -0.27 & 0.35 & -0.083 & 0.18 \\
Individuals & 1678 & 1673 & 1664 & 1673 \\
Observations & 6969 & 6966 & 6861 & 6893 \\
\hline
\end{tabular}

Note: significance levels: $+p<0.10 .{ }^{*} p<0.05 .{ }^{* *} p<0.01 .{ }^{* *} p<0.001$. Source: Swiss Household Panel (SHP) 